\title{
Tomato Juice Agar: An Alternative Media for the Cultivation of some Aspergillus Species
}

\author{
I.E. Aigbogun ${ }^{1 *}$, S.S.D. Mohammed ${ }^{1}$, C.S. Afangide ${ }^{1}$, F.E. Luka and A. Kangla ${ }^{3}$ \\ ${ }^{1}$ Department of Microbiology, Faculty of Science, Kaduna State University, Kaduna, Nigeria \\ ${ }^{2}$ Federal College of Forestry Mechanization, Alaka, Kaduna State, Nigeria \\ ${ }^{3}$ Taraba State Water Supply Agency, Jalingo, Taraba State, Nigeria \\ *Corresponding author
}

\section{A B S T R A C T}

\begin{tabular}{|l|}
\hline Key w or d s \\
Tomatoes juice \\
agar, Aspergillus sp, \\
Mycology
\end{tabular}

Tomatoes Juice Agar: an alternative media for the cultivation of some Aspergillus species was investigated. The aim of this study was to determine the efficacy of TJA to cultivate Aspergillus species. Tomato juice agar (TJA) was prepared by combining filtrate of tomatoes, glucose powder and nutrient agar for the cultivation of some Aspergillus species. Phytochemical and proximate composition of the TJ filtrate was also determined. The TJA was suitable for the growth of Aspergillus niger, Asprgillus flavus and Aspergillus fumigatus. It was observed that TJA support and quickens the growth of these fungi, therefore suitable for their growth. The phytochemical results make it formidable to inhibit bacterial while proximate revealed that $\mathrm{TJ}$ was suitable for the cultivation of these fungi. The TJA can be a quick diagnostic mycological media for the cultivation of these groups of fungi and can serve as an alternative to Potato Dextrose Agar (PDA), Saboraud Dextrose Agar (SDA) for the cultivation of selected Aspergillus species.

\section{Introduction}

Fungi are ubiquitous group of eucaryotic microorganism which can be beneficial, parasitic or saprophytic. The fungi; Aspergillus species are grouped as filamentous or multicellular. They have specific nutrient requirement for growth and survival. In general, fungi including Aspergillus species are known as slow growers therefore, have long generational time and their growth rate is affected by availability of nutrients in a system, water content, temperature, $\mathrm{pH}$ and presence of other microbes (Orukotan, 2010). Potato Dextrose Agar (PDA) and Saboraud
Dextrose Agar (SDA) are currently in use for the cultivation of these fungi because of their nutritional composition to support their growth (Chessbrough, 2009) however, possess some limitations. Commercially available PDA and SDA would need the incorporation of antibiotics such as streptomycin to hinder the growth of bacteria but the TJA needs no antibiotics for the cultivation of these fungi because of its phytochemical composition in synergy with the acidic $\mathrm{pH}$ of Tomato Juice filtrate (Orukotan, 2010). Therefore, the aim of this study was to evaluate the TJA which is an alternative media for the growth of these fungi. 


\section{Materials and Methods}

\section{Collection of culture samples}

Fungi used for this study was obtained at the pure culture bank of the Department of Microbiology, Faculty of Science, Kaduna State University, Kaduna, Nigeria.

\section{Preparation of tomatoes juice agar}

The Tomatoes Juice Agar (TJA) was prepared in the laboratory by heating $200 \mathrm{ml}$ of distilled water to about $90{ }^{\circ} \mathrm{C}$ with $6 \mathrm{~g}$ of nutrient agar added to ensure proper dissolution of the media. Fresh tomatoes was washed with clean running water to reduce microbial load and blended with a manual blender.

Exactly $40 \mathrm{ml}$ of tomatoes juice filtrate/extract was added to the water and agar. The mixture was stirred gently and $2 \mathrm{~g}$ of glucose was added thereafter to ease effervescence with no addition of antibiotics. The Tomato Juice Agar was autoclaved at $121^{\circ} \mathrm{C}$ for 15 minutes at 15 psi.The medium was allowed to moltenize at room temperature and aseptically poured into sterile petri dishes and rocked and allowed to solidify.

In summary;

Distilled water + Nutrient agar + Tomatoes Filtrate + Glucose $\longrightarrow$ TJA

The Standard Operating Procedure (S.O.P) of isolation was followed to the latter as described in Chessbrough, (2009). Using sterile syringe, inoculation was done unto the solidified TJA and incubated at room temperature.

\section{Inoculation/cultivation of fungi isolates}

Pure culture of A.niger, A. flavus and A. Fumigatus were cut aseptically unto seeded plates of Tomatoes Juice Agar and were observed for growth.

\section{Phytochemical analysis of tomatoes filtrate}

Detection of bioactive substance (Saponin, Tanin, Alkaloid) was carried out on tomatoes filtrate according to the method of Mohammed et al., (2013).

\section{Detection of alkaloids}

A fraction of the extract of TJA was treated with Wagner's reagent ( $1.27 \mathrm{~g}$ of iodine and $2 \mathrm{~g}$ of potassium iodide in $100 \mathrm{ml}$ distilled water) and observed for the formation of reddish brown coloured precipitate.

\section{Detection of flavonoids}

\section{Sulphuric acid test}

A fraction of the TJ filtrate was treated with concentrated sulphuric acid and observed for the formation of orange colour.

\section{Aqueous sodium hydroxide test}

A fraction of the TJ extract was treated with aqueous $\mathrm{NaOH}$ solution and observed for the formation of yellow-orange colouration.

\section{Detection of steroids}

Five (5) drops of concentrated sulphuric acid was added to $1 \mathrm{ml}$ of the $\mathrm{TJ}$ extract. The tube was shaken gently. The presence of steroids was indicated by the formation of reddish brown colour.

\section{Detection of saponins}

$20 \mathrm{ml}$ of distilled water was added to $0.5 \mathrm{~g}$ of the $\mathrm{TJ}$ extract in a graduated cylinder and shaken gently for 15 minutes. The formation of $1 \mathrm{~cm}$ layer of foam indicates the presence of saponin. 


\section{Detection of tannins}

About 1\%gelatin solution containing sodium chloride was added to the TJ extract.

The formation of white precipitate indicates the presence of tannins

\section{Detection of phenol}

\section{Ferric chloride test}

$2 \mathrm{ml}$ of tomatoes filtrate was taken to water and warmed at $45-50^{\circ} \mathrm{C}$. Then $2 \mathrm{ml}$ of $0.3 \%$ $\mathrm{FeCl}_{3}$ was added. Formation of green or blue color indicates the presence of phenols.

\section{Determination of percentage composition of tomato filtrate}

The proximate analysis of the samples for moisture, ash and carbohydrate contents were determined as described by AOAC (2005).

\section{Moisture content}

The moisture content was estimated by drying triplicates $10 \mathrm{~g}$ weight of the sample at $105^{\circ} \mathrm{C}$ for $24 \mathrm{hr}$ and then reweighing after cooling in a desiccator. The moisture content was expressed as percentage of the dry weight.

$$
\begin{gathered}
\text { Weight loss of sample } \\
\text { Meisture content }=\text { - } \\
\text { Weigh of the original sample }
\end{gathered}
$$

\section{Ash content/mineral content}

Two grams of the dried sample was weighed into a dry porcelain dish and then heated in amuffle furnace at $6000 \mathrm{C}$ for 6 hours before being cooled in desiccators and weighed. The percentage ash content was calculated thus:

$$
\% \text { ash }=\frac{\text { Weight of ash }}{\text { Weight of sample }}
$$

\section{Crude protein}

One gram of each sample was weighed into a digestion flask. Ten grams of potassium sulphate, $0.7 \mathrm{~g}$ mercuric oxide and $20 \mathrm{~cm}^{3}$ concentrated sulphuric acid was added to the sample in the digestion flask. The flask was heated gently at an inclined angle until frothing subsides and boiled until the solution became clear. This continued for half an hour.

When the frothing was in excess, a small amount of paraffin wax was added. On cooling, 90ml of distilled water was added and mixed. A small piece of pumice was added to prevent bumping. $80 \mathrm{ml}$ of $2 \mathrm{M}$ sodium hydroxide solution was added while tilting the flask so that two layers were formed. The condenser unit was then connected, heated and the distilled ammonia collected in $50 \mathrm{ml}$ boric acid / methyl red indicator. Fifty milliliter $(50 \mathrm{ml})$ of the distillate was titrated against $0.1 \mathrm{M}$ hydrochloric acid solution.

The percentage nitrogen content percent was calculated thus:

$$
\begin{gathered}
\text { (Volume of acid x } \\
\text { Molarity of standard acid) x } 0.014
\end{gathered}
$$

\section{Fat content}

Two grammes of the sample was weighed into the Soxhlet extraction thimble. Cotton wool was used as plug to avoid loss of sample. The thimble was transferred into the Soxhlet extractor and sufficient petroleum ether was added until the latter is siphoned into the receiving flask which has been weighed.

More ether was poured to cover the thimble completely and flask placed with the extractor on the electric heating mantle. The reflux condenser was heated gently for 3hours, 
switched off and allowed to cool for 10 minutes. Recovered solvent was transferred into an air oven $\left(100^{\circ} \mathrm{C}\right)$ for 1 hour and then cooled in desiccators and weighed. The amount of oil produced was calculated and expressed as percentage of original sample.

Weight loss of sample (extracted fat) $\%$ Fat $=$

$$
\text { Weight of sample }
$$

\section{Total carbohydrate content}

The total carbohydrate was determined by differential method i.e. by subtracting the total protein, lipid, moisture and ash content from 100.

Thus:

$\%$ carbohydrate $=(100-(\%$ moisture $+\%$ ash $+\%$ fat $+\%$ protein $+\%$ fibre $)$

\section{Results and Discussion}

After inoculation of the Aspergillus isolates on TJA, growth were observed after 24 hours and the colonial morphology is shown in table 1. Microscopic examination was carried out on the isolates to confirm the Aspergillus species. A. niger, A. flavus and A. fumigatus showed the same morphology and microscopic similarity with the standard result of Funder, (1961) and this is in similarity to the report of Diba et al., (2007). Phytochemical constituent showed positive for carbohydrate, steroid, saponin, tannin and Flavonoid. This result is similar to the findings of Pochapski et al., (2011). This phytochemical attribute, in synergy with the acidic $\mathrm{pH}$ of the tomatoes filtrate is responsible for not using antibiotic(s) to hinder the growth of bacteria. The presence of alkaloid in the filtrate act as an antibacterial bioactive substance which may be static or cidal effect as reported by Cushnie et al., (2014).

Table.1 Cultural appearance and microscopic examination of the fungi isolates on tomatoes juice agar

\begin{tabular}{|c|c|c|}
\hline Fungi sp & Macroscopy & Microscopy \\
\hline A. flavus & $\begin{array}{l}\text { Green at the topical } \\
\text { surface, while pink } \\
\text { below the topical } \\
\text { surface. }\end{array}$ & $\begin{array}{l}\text { Septate hyphae, } \\
\text { individual } \\
\text { conidiophores, } \\
\text { carries conidia at the } \\
\text { top head in the form } \\
\text { of bulb }\end{array}$ \\
\hline A. fumigatus & $\begin{array}{l}\text { Dark green with } \\
\text { powder production }\end{array}$ & $\begin{array}{l}\text { Septate hyphae, } \\
\text { Individual } \\
\text { conidiophores with } \\
\text { end bulb that carries } \\
\text { much disperse } \\
\text { conidia }\end{array}$ \\
\hline A.niger & $\begin{array}{l}\text { Black colour on } \\
\text { TJA }\end{array}$ & $\begin{array}{l}\text { Septate hyphae, } \\
\text { Individual } \\
\text { conidiophores with } \\
\text { long tip }\end{array}$ \\
\hline
\end{tabular}


Table.2 Qualitative phytochemical screening of tomatoes juice extract

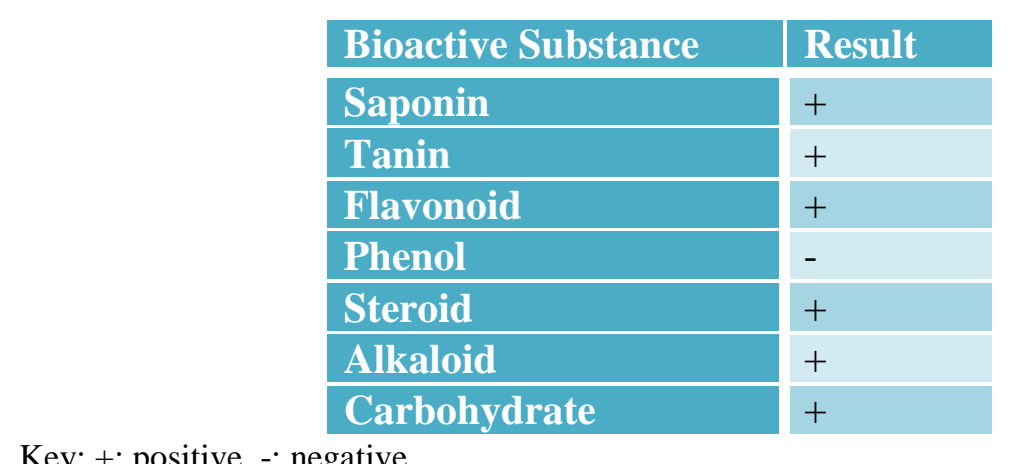

Key: +; positive, -; negative

Table.3 Proximate composition of tomatoes juice filtrate

\begin{tabular}{|l|c|}
\hline Parameters (\%) & Percentage Composition \\
\hline Moisture & 93.08 \\
\hline Ash & 0.80 \\
\hline Crude Protein & 1.09 \\
\hline Crude fat & 0.67 \\
\hline Carbohydrate & 3.17 \\
\hline
\end{tabular}

However, the acidic medium synergistically reduces the risk of bacterial contamination. Proximate composition of $\mathrm{TJ}$ filtrate in increasing order contains percentage carbohydrate, protein, ash, fat and high moisture content. This result is in absolute agreement with the result of Abdullahi et al., (2016). The ash content is made up of minerals and vitamins of natural substrate should not exceed 5\% while that of processed substrate is at 10\% (McClements, 2003). Therefore, TJ filtrate is a natural substrate suitable for the cultivation of these fungi (Table 2 and 3 ).

This research has revealed that TJM can be used as a rapid and suitable conventional media for the cultivation of A. niger, A. flavus and A. fumigatus especially for research and clinical findings in research institute and hospitals as a fast diagnostic culture media.

\section{References}

Abdullahi, I. I., Abdullahi, N., Abdu, A. M. and Ibrahim, A. S. (2016). Proximate,
Mineral and Vitamin Analysis of Fresh and Canned Tomato. Biosciences Biotechnology Research Asia, 13(2), 1163-1169.

Association of Official Analytical Chemists. (2005). Official Methods of Analysis of Association of Official Analytical Chemist International, $20^{\text {th }}$ edition. Arlington, Washington D.C. pp 69, 80.

Chessbrough, M (2014). District Laboratory Practice in Tropical Countries. $2^{\text {nd }}$ Edition, Cambridge University Press, pp33-34.

Cushnie, T. T., Cushnie, B. and Lamb, A. J. (2014). Alkaloids: an overview of their antibacterial, antibiotic-enhancing and antivirulence activities. International Journal of Antimicrobial Agents, 44(5), 377-386.

Diba, K., Kordbacheh, P., Mirhendi, S. H., Rezaie, S. and Mahmoudi, M. (2007). Identification of Aspergillus species using morphological characteristics. Pakistan Journal of Medical Sciences, 23(6), 867. 
Funder, S. (1961). Practical Mycology. Manual for identification of fungi. $2^{\text {nd }}$ edition, Brøgger Publisher, pp. 15-16, 94-97.

Grozeff, G. E. G., Senn, M. E., Alegre, M. L., Chaves, A. R. and Bartoli, C. G. (2016). Nocturnal low irradiance pulses improve fruit yield and lycopene concentration in tomato. Scientia horticulturae, 203, 47-52.

McClements, J. (2003). Analysis of Ash and Minerals. Analysis of Food Products: Food Science 581 Class Notes.

Mohamed, A. A., Ali, S. I., and El-Baz, F. K. (2013). Antioxidant and Antibacterial Activities of Crude Extracts and
Essential Oils of Syzygium cumini Leaves. Public Library of Science, 8(4), 60269.

Orukotan, A.A. (2010). Introduction to Mycology. $\quad 2^{\text {nd }}$ Edition, Global Pacesetter Publishing House, Kaduna, Nigeria, pp 34-38.

Pochapski, M. T., Fosquiera, E. C., Esmerino, L. A., dos Santos, E. B., Farago, P. V., Santos, F. A. and Groppo, F. C. (2011). Phytochemical screening, antioxidant, and antimicrobial activities of the crude leaves' extract from Ipomoea batatas (L.) Lam. Pharmacognosy magazine, 7(26), 165.

\section{How to cite this article:}

Aigbogun, I.E., S.S.D. Mohammed, C.S. Afangide, F.E. Luka and Kangla, A. 2018. Tomato Juice Agar: An Alternative Media for the Cultivation of some Aspergillus species. Int.J.Curr.Microbiol.App.Sci. 7(05): 788-793. doi: https://doi.org/10.20546/ijcmas.2018.705.095 